\title{
Efficacy of the Devolved System of Governance in Management of Land Use Conflicts in West Pokot County, Kenya
}

\author{
Andrew Nyongesa Mung'ale, Frank Khachina Matanga, Edmond Were \\ Department of Peace and Conflict Studies, Musinde Muliro University of Science and Technology, Kakamega, Kenya \\ Email: andrewmungale@gmail.com,fmatanga@mmust.ac.ke,dr.were@kisiiuniversity.ac.ke
}

How to cite this paper: Mung'ale, A. N., Matanga, F. K., \& Were, E. (2021). Efficacy of the Devolved System of Governance in Management of Land Use Conflicts in West Pokot County, Kenya. Open Journal of Social Sciences, 9, 279-304.

https://doi.org/10.4236/jss.2021.93019

Received: December 25, 2020

Accepted: March 21, 2021

Published: March 24, 2021

Copyright $\odot 2021$ by author(s) and Scientific Research Publishing Inc. This work is licensed under the Creative Commons Attribution International License (CC BY 4.0).

http://creativecommons.org/licenses/by/4.0/

\begin{abstract}
The devolved system of governance radically transformed structures and institutions of governance in Kenya. The system of governance is designed as a unitary state with the national government and 47 county governments. It establishes shared governance at national level and self-governance at county level. The system of governance transformed the administration and management of land use in Kenya. The Ministry of Land and Physical Planning, the county government and the National Land Commission have powers and authority to perform functions that improve administration and management of land use. The cooperation of the Ministry of Land, the county governments and the National Land Commission in administration and management of land is held, used and managed in a manner that is equitable, efficient, productive and sustainable. Despite the establishment of the devolved system of governance, West Pokot County has continued to experience intractable and protracted land use conflicts in low lands of Chesegon, Sigor, Alale, Cheptulel, Kacheliba, Chepkopegh and Kanyarkwat as well as highlands of Chepararia, Lelan and Kapenguria. The study sought to assess the efficacy of the institutions of the devolved system of governance in the management of land use conflict in West Pokot County. The objective of this study is to examine the influence of the institutions of the devolved system of governance in management of land use conflicts in West Pokot County. The study used consociational democracy theory as expounded by Arend Lijphart. The theory postulates that internal conflicts in divided countries are managed by the transfer of power and resources from national government to autonomous regional government to harness shared governance and self-governance through participation, inclusion and effective service delivery. The study used descriptive and explanatory research design to describe the characteristics, explain and predict the relationship between institutions of the devolved system of
\end{abstract}


governance and management of land use conflicts in West Pokot County. Data was collected using questionnaire, interview schedules, focused discussion and observation. It was analyzed using SPSS and coding of themes and findings presented using tables, charts and narrations. The study found out that the design of institutions in the devolved system of governance is effective in management of land use conflicts in West Pokot County.

\section{Keywords}

Devolved System of Governance, National Government, County Government, Conflict Management, Land Use Conflicts in West Pokot County

\section{Introduction}

The devolved system of governance is an instrument for managing internal conflicts in divided countries. The system has been adopted by developed and developing countries to manage diversity and prevent the prevalence of intrastate conflicts which characterized the post Cold Period. Kenya has been riddled with violent conflict from independence in 1963 (Roberts, 2009; Oyugi, 2000). The mismanagement of land question and the control of arms of government transited to ethnic discrimination, marginalization and conflicts. Unresolved land question has always taken political and ethnic undertones (Rift Valley, Nyanza, Western and Parts of Coastal province) (Nyukuri, 1997; Kanyinga et al., 2008). The multiparty politics in 1990s triggered ethnic clashes of 1992 and 1997 in areas where land is a key fault line. But the magnitude of 2007/8 post-election violence threatened the existence of the Republic of Kenya. It adversely affected politics, economy and social development. The piecemeal land reforms were rendered useless in the face of a collapsing state (Roberts, 2009; Mwenda, 2010). Kenya took a raft of measures which included the adoption of the devolved system of governance in the Constitution of 2010 as a comprehensive tool for managing diversity as well as land which has been at the centre of conflicts from colonial period.

The devolved system of governance is designed to address the weaknesses of the centralized system of governance, promote economic development and manage internal conflicts (Ouma, 2011; Bosire, 2013). The system of governance is anchored on the democratic and accountable exercise of power; self-governance and participation in decision making and recognition of community in management of their own affairs and equitable sharing of resources (Art. 174 of the Constitution of Kenya, 2010).

The design of the devolved system of governance radically altered the institutional framework for land administration and management of land use in Kenya. The design established the national government, the county governments and the National Land Commission to administer and manage land use (Kameri-Mbote, 2016). The institutions of the devolved system of governance are de- 
signed to ensure equitable access to land; security of land rights; sustainable and productive management of land resources; transparent and cost effective administration of land sound conservation and protection of land; and encouragement of communities to settle land disputes through recognized local community initiatives consistent with the constitution of Kenya. The national government, county governments and National Land Commission are further mandated to perform concurrent and exclusive functions to ensure land in Kenya are held, used and managed in a manner that is equitable, efficient, productive and sustainable (Article 60 of the Constitution of Kenya, 2010).

Despite the establishment of the institutions of the devolved system of governance to administer and manage land use, conflicts continue to occur in West Pokot County. The protracted land use conflicts have occurred in the lowlands of Chesegon, Sigor, Alale, Kacheliba, Chepkopegh and Kanyarkwat as well as highlands of Chepareria, Lelan and Kapenguria in West Pokot County. In 2012 more than 30 people on the Pokot-Turkana border and more than 80 people died as a result of land use conflicts in West Pokot County (Pragya, 2013). The county lost 120 people on its border with Elgeyo/Marakwet county in 2018 (Wu, 2019).

Land remain a highly emotive natural resource and with fault line which is easily triggered into violent conflicts in the county (Hornsby, 2012; Odote, 2013). Therefore, this study seeks to assess the efficacy of the institutions of the devolved system of governance in administration and management of land use conflicts in West Pokot County. The objective of this study is to examine the influence of the institutions of the devolved system of governance in administration and management of land use conflicts in West Pokot County, Kenya.

\section{Theoretical Framework}

Land distribution is a major challenge to developing countries. Skewed distribution of land as a natural resource has caused conflicts in many countries. Ethnic conflicts in Africa may not be as results of poor allocation of resources by authoritarian leaders in a centralized system of governance but it is not ethnic difference that causes the conflicts. Kanyinga et al. (2008) also point out that the mismanagement of land reforms in Kenya by President Kenyatta, Moi and Kibaki metamorphosized into ethnic hatred and conflicts. Land was used as a political to obtaining support and sustaining power instead of establishing effective institutions to administer and manage it fairly and equitably. Land is a key fault line for many internal conflicts in Kenya due to poor administration and mismanagement (Manji, 2014). Boone (2012) noted that highly politicized land conflict continues because redistributions of land is a game that always create winners and losers in many countries. Some land reforms such as the Swynnerton Plan of 1954 and the Resettlement of Africans in former European holdings created more landless and squatters in Kenya, which the reformed institutions of the 
devolved system of governance must address and prevent vulnerability to violent conflicts.

West Pokot County has experienced conflicts related to land use from colonial period when they were displaced from their grazing land in Trans-Nzoia County (Nangulu, 2009). Land use conflicts are more pronounced in agriculturally productive and settled places and also along riverine areas where crop farming/furrow irrigation is practiced in West Pokot County (Pkalya, et al. 2004). The competition over land, pasture and water by nomadic pastoralists and agro-pastoralists coupled with different types of land tenures systems has intensified violent conflicts in West Pokot County. Huho (2012) analyzed the intractable and protracted conflicts in West Pokot County. He observed that despite the many strategies put in place to manage conflicts, they were persisting. $\mathrm{He}$ argued that there was a missing-link between the conflicts and the strategies put in place to manage them in West Pokot County. This seeks to find out whether the missing link between the conflicts and the strategies was the devolved system of governance.

Nyberg et al. (2015), examined the effect of land enclosures in transforming land, livestock and livelihoods in West Pokot County. The results of the study indicated that the land enclosures provided the opportunities for a pathway towards a sustainable livestock-based agro-pastoral system but it was threatened by the risks of conflicts and inequalities in relation to land, triggered by the weakening of collective property rights. Other studies (Nangulu, 2009; Masinde, et al. 2004) have analyzed different aspects of conflicts linked directly or indirectly to land use in West Pokot, however, there are limited empirical studies on the efficacy of the institutions of the devolved system of governance in administration and management of land use conflicts in West Pokot County. This study used consociational democracy theory to describe, explain and predict the relationship between the institutions in the devolved system of governance and management of land use conflicts in West Pokot County.

The study used the consociational democracy theory to describe and explain the link between the institutions of the devolved system of governance and management of land use conflicts in West Pokot County. The main proponent of this theory is Arendt Lijphart (1999). The theory was later refined by McGarry and O'Leary when they underscored the transfer of power and territorial self-governance in democratic states (Wolff, 2012). Lijphart postulated that democracy and social peace can be secured in deeply divided societies if elites engage in accommodative behaviour and forsake centrifugal competition in a self-negating prediction (Bogaards, 2002). The theory states that fragmented society or divided society is capable of maintaining peaceful and stable political system through the transfer of power and through the territorial self-governance. The institutional arrangements born out of power sharing or territorial self governance are designed to manage internal conflicts from national to the regional autonomous units of government. The design delivers effective and efficient ser- 
vices in places where the presence of government was missing at the peripheries of the country. It improves participation of the community in decision making, elections of leaders who understands the challenges at county level and prioritize them based on their impact on community development.

The consociational democracy theory informed the design of the devolved system of governance in Kenya which is composed of the national government and 47 county governments. The system is organized in a way that the national and county governments are distinct and interdependent but cooperate in executing their exclusive and concurrent functions in administration and management of land use conflicts. The national and county governments have the mandate to administer and manage intractable and protracted land use conflicts in West Pokot County. The national government, county governments and the National Land Commission have authority and functions to ensure land is held, used and managed in a manner that is equitable, efficient, productive and sustainable based on the principles of land policy.

\section{Methodology}

\subsection{Research Design}

This study used descriptive and explanatory designs to examine the influence of the devolved system of governance on the management of land use conflicts in West Pokot County. The descriptive and explanatory designs were used for conducting systematic observation, description and explanation of the influence of the design of the devolved system of governance in the management of land use conflicts in West Pokot County. The designs guided the choice of study area, sampling process of the targeted population of the study, instruments of data collection, data analysis and presentation of the findings.

The descriptive research design enabled the researcher to accurately and systematically describe the phenomena or characteristics of the design of the devolved system of governance in West Pokot County. The descriptive design facilitated the discovering of meanings, description of real system in the study areas, determine the frequency with which households interact with it and categorize useful information on it. The design was useful in guiding observation, description and documentation aspects of the devolved system of governance as it naturally occurs in the study area and the discovery of associations or relationships between or among selected variables of the study (Dulock, 1993). The explanatory research design was used to complement descriptive design. It was used to explain and account for the descriptive information obtained through descriptive design. It enabled the researcher to go beyond the "what" to "why" or "how" questions. The explanatory research designs dealt with questions such as the causes and how the devolved system of governance manages conflicts and provided evidence to support or refute an explanation or prediction of the relationships between the system and land use conflicts.

In this study the descriptive design was used to accurately and systematically 
described the design of the devolved system of governance and management of land use conflicts in West Pokot. It sought to discover new meaning, describe what exists and categorize information on devolved system of governance as well as discovered the associations or relationships with conflict management mechanisms. The explanatory design attempted to explain and predict the influence of the devolved system of governance on management of land use conflicts in West Pokot County.

\subsection{Study Area}

West Pokot County is situated in the northwest part of Kenya, along the border with Uganda. The county borders Turkana County to the North and North East, Trans-Nzoia County to the South, Elgeyo-Marakwet County and Baringo County to the South East and East respectively. It also borders Upe in the West and Sebei district in Uganda in the Southwest (Nangulu, 2009). The County has the following sub-counties: West Pokot (Kapenguria, Sook and Kongelai); South Pokot (Lelan, Chepareria and Tapch); Pokot Central (Sigor and Chesegon) and North Pokot (Kacheliba, Alale, Kasei, Kiwawa, Konyao).

About $60 \%$ of the population live in the lowlands in Alale, Kacheliba, Chesegon and Sigor divisions. The high settlement density of population is found in the highlands of Chepareria, Lelan and Kapenguria. The competition over land, pasture and water by nomadic pastoralists and agro-pastoralists coupled with different types of land tenures has intensified violent conflicts across the county over equitable access to land, security of land rights and sustainable and productive management of land resources (Huho, 2012). The county experiences intra and inter community conflict over the control and use of pasture and water for livestock in the Lowlands of Chesegon, Sigor, Alale and Kacheliba. Land ownership conflicts have triggered boundary conflicts in lowlands of Sigor, Cheptulel, Kacheliba, Chepkopegh and Kanyarkwat and highlands of Chepararia, Lelan and Kapenguria (West Pokot County Commissioner, 2018). There are increasing intracommunity conflicts in the form of boundary disputes, livestock trespassing on enclosed land and internal family disputes related to land use and land ownership (Nyberg et al. 2015).

\subsection{Study Population}

West Pokot County has a population of 618,867 people and 116,182 households based on 2019 Kenya Population and Housing Census. The household heads who by all standard interact with institutions of the devolved system of governance were in a better place to paint a picture of its efficacy in administration and management of land in West Pokot County. The national and county government officials from the Ministry of Interior and Coordination of National Government; the Ministry of Lands and Physical Planning and the National Land Commission provided in-depth data on the linkages between the structures and institutions of the devolved system of governance and how they con- 
tribute to the management of land use conflicts in West Pokot County. The study population also included the officials of the West Pokot County Government; politicians (Members of the County Assembly) in charge of Land Committee in the County Assembly of West Pokot County, NGO officials and Council of elders in West Pokot County.

The study used probability sampling to obtain representative sample of household heads from 116,182 households. The representative sample was suitable for the objective of this study which sought to examine influence of the institutions of devolved system of governance on administration and management of land use in West Pokot County. The institutions enhanced community participation, governance, democracy, transparency and accountability in administration and management of land which reduced conflicts caused by weak institutions or lack of presence of government in the county. Therefore, a representative sample of household heads provided a useful description of the study population on the influence of institutions of devolution on land use management.

The study used cluster sampling design to obtain representative sample. Given the nature of nomadic pastoralists in the lowlands of West Pokot County, it was impossible to access households in the same place. The research clustered the subcounties, locations, sublocations and villages, where the sample was selected without having the initial list of all households in the county (Babbie, 2007). The sample size of household heads was determined using a web-based calculator of Survey Systems by Zar, (1984) as quoted by Ogecha (2016). The formula was as follows

$$
\begin{gathered}
\mathrm{SS}=\mathrm{Z}^{2} *(\mathrm{P}) *(1-\mathrm{P})=2^{2} *(0.5) *(1-0.5)=400 \\
\mathrm{C}^{2} \\
0.05^{2}
\end{gathered}
$$

where:

SS = Sample Size;

$\mathrm{Z}=\mathrm{Z}$ value (e.g. 2 for $95 \%$ confidence level);

$\mathrm{P}=$ percentage picking a choice, expressed as decimal (0.5 used for sample size needed);

$\mathrm{C}=$ confidence interval, expressed as decimal (e.g., $0.05= \pm 5$ ).

Source: (Zar, 1984)

A sample size of 400 with a confidence interval of $95 \%$ and a margin error of $5 \%$ was arrived at. The sample size was distributed to four subcounties in West Pokot County. Each subcounty was given 100 questionnaires from the sample of 400. The copy of questionnaires in each subcounty was further subdivided into locations in order to obtain representative data from the four subcounties, in West Pokot County, Kenya. In addition, the study used purposeful sampling design to obtain sample from national government, county government, National Land Commission and civil society officials. It also used both convenience and snowballing to select government officials, civil society officials, politicians and members of the council of elders in West Pokot County (Bryman \& Teevan, 2005). 


\subsection{Data Collection and Analysis}

The study used both primary and secondary data. The primary data was collected from study area using the questionnaire, interviews, observation and focused group discussions. The secondary data was collected from the Kenya National Bureau of Statistics Census Reports and Economic Survey Reports, West Pokot County Government Reports, World Bank Reports, thesis, books, journals, articles and magazines. The quantitative data was analyzed using Statistical Package for Social Scientists Version 20.0 (SPSS 20.0) to obtain descriptive statistics such as frequencies and percentages. It was presented using tables, charts and graphs. The qualitative data was coded and analyzed using themes to provide in-depth information on the explanation and prediction of the relationships between the institutions in the devolved system of governance and management of land use conflicts in West Pokot County. The qualitative data was presented using narrative reports and verbatim quotations.

\section{Study Findings and Discussion}

\subsection{Demographic Characteristics of Household Heads in West Pokot County, Kenya}

The study considered the following demographic characteristics of household heads: gender, age bracket and level of education in West Pokot County. These intervening variables had a bearing on the findings of the household heads who respondent to this study in West Pokot County.

\subsubsection{Gender of Household heads in West Pokot County}

The study sought to determine the gender of the household heads who responded to the questionnaire of the study in West Pokot County. The results of the findings on the gender of the household respondents are illustrated in Figure 1.

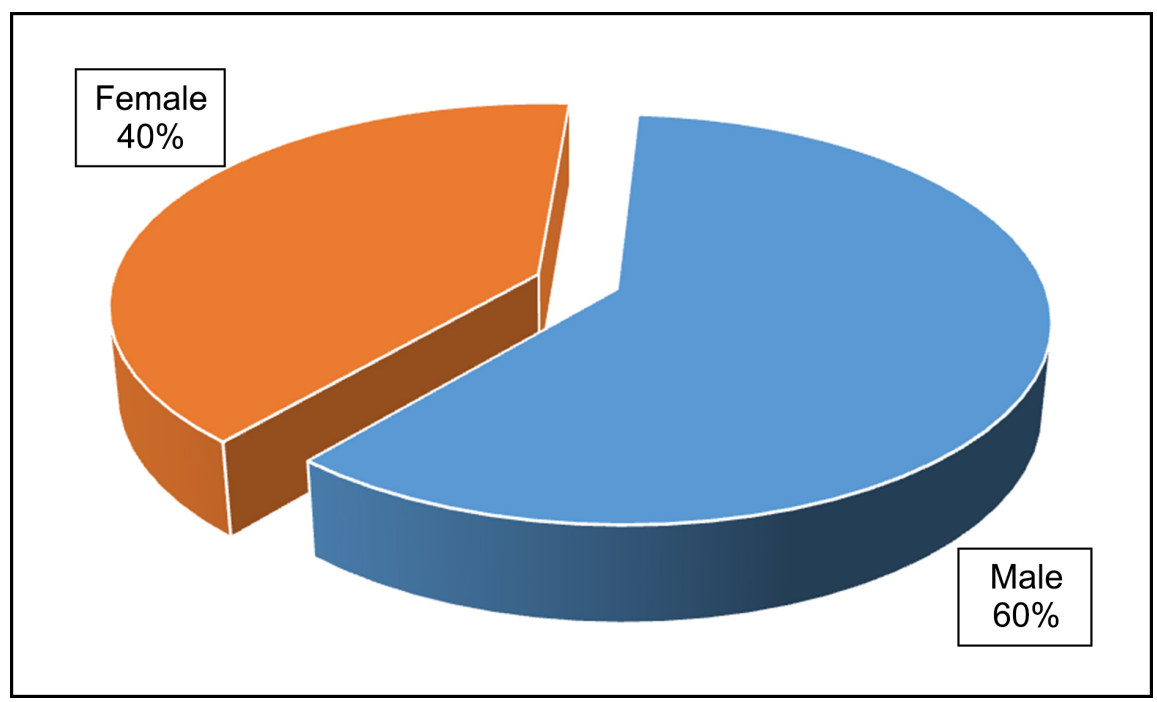

Figure 1. Gender of household respondents in West Pokot County. Source: Field data, (2018). 
Figure 1 shows that out of the 384 household heads who responded, 231 (60.2\%) respondents were male while 153 (39.8\%) respondents were female. The result shows that there were more male than female household heads who responded to this study. The difference between the genders was more than $20 \%$. This gender differences reflects the deep-rooted patriarchal nature of households in West Pokot County. It also indicates the role of gender in economic development and therefore, gender imbalance significantly affects equitable access to land, security to land rights, sustainable and productive management of land in West Pokot County.

It emerged from interviews and focused group discussions that gender imbalance was affecting equitable access to land and there was need to eliminate gender discrimination in law, customs and practices related to land and property in land. Gender imbalance was influencing accessibility to land, security of land rights and sustainable use of land in West Pokot County. For instance, it emerged from interviews, focused group discussions and observations that the patriarchal nature of the Pokot culture was affecting the status of female and their capacity to access and use land in the county. One of the chiefs said that their culture was very clear on the roles of different genders in a home. Culture defines the roles and resources in a home which were under the full authority and control of female and male gender. Land is one of the most important resource of the family which was under the authority and control of male gender but female had a right to use but not to own it. This cultural belief seemed to have more wait on the conscience of the people more than Article 2(4) of the Constitution of Kenya which prohibits "Any law, including customary law, that is inconsistent with the constitution was void to the extent of the inconsistency, and any act or omission in contravention of the constitution was invalid."

According to Odote (2013), traditional customary practices in Kenya and many other African countries ignored the right of female in the management of land. The female could only access land through their husbands or their fathers. Persist gender discrimination was affecting the efficacy of the institutions of the devolved system of governance in administration and management of land use conflicts in the county. Since land was a very important factor of production, accessibility and security of land rights were being denied not by the laws, policies or programmes but by cultural believes. The Article 2(4) of the Constitution of Kenya 2010 prohibit gender discrimination and includes "elimination of gender discrimination in law, customs and practices related to land and property in land" as one of the principles of land policy (Odote, 2013).

Agrawal et al. (2006) argues that devolved system of governance effectively manages conflicts where gender equity is achieved. The system ought to give all people power to govern themselves, participate in decisions making and empower the community to manage their own affairs and further their development. Gender inequity is an upfront to the rights of female to own, inherit, dispose-off land, manage and participate in management of land conflicts. Cultural 
practices that perpetuate gender inequity undermine and put the rights of female under constant attack from customs, laws, and individuals including government officials who believed that female could not be trusted with or they do not deserve to own land are forced to change their mind set.

The devolved system of governance must prioritize implementation of the principles of land policy on elimination of gender discrimination in law, customs and practices related to land and property in land and other affirmative actions in order to enhance the efficacy of the institutions of the devolved system of governance in managing land use conflicts in West Pokot County. It will allow gender equity in engagement in core principles devolution, that is, participation and representation in decision making affecting them with regards to land issues.

\subsubsection{Age Bracket of Household Heads in West Pokot County}

The study sought to examine whether age brackets of the household heads had an influence on the effectiveness of the design of the devolved system of governance in managing of land use conflicts in West Pokot County. The results of the respondents were tabulated in Table 1.

Table 1 indicates the perceptions of different age brackets of household heads towards the design of the devolved system of governance in West Pokot County. The result shows that 86 (22.4\%) of household heads were in the age bracket of 31 to 35 years; 71 (18.5\%) were in the age bracket of 26 to 30 years; 70 (18.2\%) were in age bracket of 36 to 40 years; $62(16.1 \%)$ were below 25 years of age bracket; $42(10.9 \%)$ were above 51 years; 28 (7.3\%) were 46 to 50 years and 25 (6.5\%) were 41 to 45 years. The result shows that majority of the household heads $22.4 \%$ were in the age bracket of 31 - 35 years while the least (6.5\%) was in the age bracket of 41 to 45 years. Indeed, the most active and economically productive

Table 1. Influence of the age brackets of the household heads on the efficacy of the design of the devolved system of governance in management of land use conflicts.

\begin{tabular}{ccc}
\hline & Frequency & Percent \\
\hline Below 25 years & 62 & 16.1 \\
$26-30$ years & 71 & 18.5 \\
$31-35$ years & 86 & 22.4 \\
$36-40$ years & 70 & 18.2 \\
$41-45$ years & 25 & 6.5 \\
46 - 50 years & 28 & 7.3 \\
Above 51 years & 42 & 10.9 \\
Total & 384 & 100.0 \\
\hline
\end{tabular}

Source: Field Data (2018). 
age bracket was 31 to 35 years. That was the age bracket where most youth were establishing their families and they needed land as a source of their livelihood as well as for building their homesteads. However, it should be noted that instead of the age increasing or decreasing gradually, from $31-35,36$ - 40 and 41 - 45, it drastically dropped from $18.2 \%$ (36 - 40) to $6.5 \%$ (41 - 45).

The finding shows that age brackets had an influence on the effectiveness of the design of the devolved system of governance on management of land use conflicts. From the 26 years to 40 years, household heads had responsibility to their families, community and the county. They need land for pastoralism or agroagriculturalism, therefore, any institutions of government which enhanced the process of them accessing, controlling, owning or using land was supported, that is why most of them supported the devolved system of governance. Age bracket has direct link to administration and management of land which was likely to reduce conflicts related to land use.

\subsubsection{Level of Education}

This section sought to determine whether the levels of education of household heads had influence on the effectiveness of the design of the devolved system of governance in managing land use conflicts in West Pokot County. The results of the distribution of the levels of education of household were summarized in Figure 2.

The results in Figure 2 show the levels of education of the household heads in West Pokot County. The result shows that 103 (27\%) household heads had tertiary college education; 79 (21\%) household heads had secondary education; 65 (17\%) of household heads had primary education; 53 (14\%) household heads had vocational training education; 42 (11\%) had university education and 42 (11\%) other levels of education.

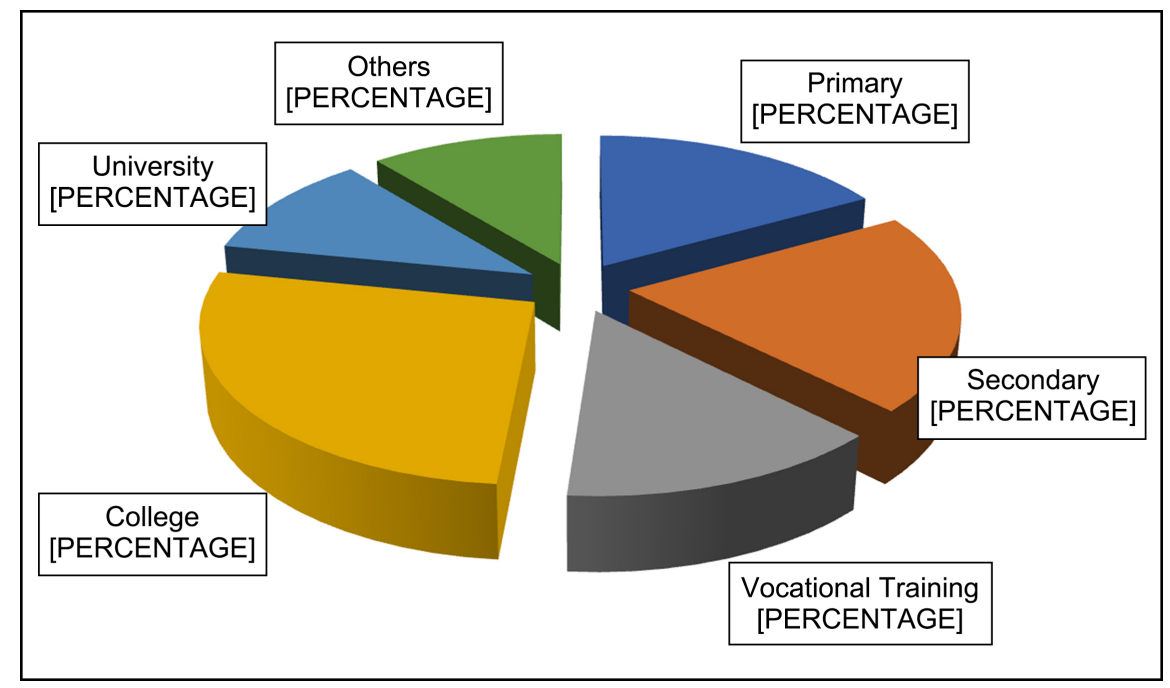

Figure 2. Levels of education of household heads had influence on the efficacy of the design of the devolved system of governance managing land use conflicts. Source: Field data, (2018). 
During the administration of questionnaires to household respondents, it was observed that many household heads were assisted to fill the questionnaire yet only $14.3 \%$ indicated that they were illiterate. Although the county government reports confirmed the level of illiteracy in the county. The report indicated that the literacy level in the county was estimated at $60 \%$ (County Government of West Pokot, 2014). The county government was addressing this challenge allocating more resources in its budget towards education sector in order to achieve the Governor's “Three E" agenda. The "Three E" stand for Economic, Equity and Education. The investment in education was expected to liberate and empower the community to understand their crucial role in the governance system so that they could participate in decision making, hold leaders accountable, seek transparent and efficient service delivery. This was going to enable the community to take the opportunities provided by the design of the devolved system of governance to empower the citizens to participate in self-governance at county level and shared governance at national level.

The improvement of the levels of education of household heads was very important because it was going to expedite development, equity, civic duties and public participation in administration and management of land use in the county. For instance, a senior officer in the county government argued against transformation of community land to private land among the pastoralists. The officer pointed out that subdivision of community land to private land was going to hinder effective practice of pastoralism which required pastoralists to move from place to place in search of pasture and water in arid and semi-arid land which had minimum rainfall. Privatization of communal land was transferring communal land ownership and security of land rights to individuals who were selling land, fencing or subdividing land just as it did happen in Kajiado County, where individuals subdivided and sold land and became paupers. Nyberg et al. (2015) concurs with senior county government officer that use of land enclosures as part of privatization of land had both opportunities and challenges. Many people had lost access to enclosed land and they had resorted to unsustainable harvesting of firewood on government land to make end meet, emergence of boundary conflicts, livestock trespassing on enclosed land and internal family disputes related to land use and land ownership was on the increase in the county.

Therefore, the levels of education of household heads were important in self-determination and in enabling the national and county governments to implement land reforms in the county. The literate population will take advantage of the opportunities created by land reforms such as titling which will enable the residence to access loans using their title deeds and allowing the investors to invest in the county where security of land rights was guaranteed. The level of education will enable the public to participate in the implementation of laws, policies and administrative actions which will lead to protection of community interests and effective management of land use conflicts in West Pokot County. 
The improved levels of education of household were important in determining the effectiveness of the design of the devolved system of governance in influencing management of land use conflicts in West Pokot County. This is because, educated residents would positively engage in decision making, put their government on toes, elect suitable leaders and ensure land effectively and efficiently managed.

\section{Efficacy of the Design of the Devolved System of Governance in Management of Land Use Conflicts in West Pokot County}

The devolved system governance in Kenya consists of the national, county governments, constitution commissions and interdependent offices. The Fourth Schedule highlights both concurrent and exclusive authority and functions of national and county governments (Art. 186). Further, Art. 187 also indicates that a function or power of government at one level may be transferred to a government at the other level by agreement between the governments. Thus, the powers and functions of national and county governments are clearly distributed or shared to ensure efficient and effective services delivery across the country.

The institutions of the devolved system of governance reformed the administration and management of land use. The institutions aimed at giving powers of self-governance to the people and enhancing their participation in the exercise of the powers of the state and in making decisions affecting them. They have recognized the rights of communities to manage their affairs and to further their development. They facilitate the decentralization of state organs, their functions and services from the centre to county level as well as to enhance checks and balances and the separation of powers which lead to effective and efficient delivery of services, thus, improving administration and management of land which may directly mitigate land use conflicts in West Pokot County.

This section attempts to examine the efficacy of the institutions of the devolved system of governance at both national and county levels in influencing the administration and management of land use which transforms conflicts. The first part of this section analyses the influence of the national government institutions tasked with administration and management of land use conflicts. The second part focuses on the institutions at county government of West Pokot tasked with administration and management of land use conflicts at county level. The section concludes by pointing out that the institutions in the national and county governments are designed to work together to achieve the desired principles of land policy.

\subsection{Efficacy of Institutions in the National Government Engaged in Administration and Management of Land Use Conflicts in West Pokot County}

The devolved system of governance radically transformed structures and institu- 
tions of governance in Kenya. The structures and institutions provide a framework through which land reforms are being implemented to manage land use conflicts. Therefore, this section seeks to examine the efficacy of the institutions in the national government tasked with the responsibility of administering and managing land use conflicts in West Pokot County. The results are shown in Table 2.

The result in Table 2 shows the perception of household heads with regards to institutions in the national government dealing with land use. The result shows that most of the household heads, that is, 126 (33\%) associated the Ministry of Interior and Coordination of National Government (County Commissioner, Deputy County Commissioners, Assistant County Commissioners, Chiefs and Subchiefs) with administration and management of land use conflicts in West Pokot County. Only 93 (24.2\%) of household respondents associated the Ministry of Land and Physical Planning with administration and management of land use conflicts in West Pokot County. The 91 (24\%) of household head respondents associated the National Environment and Management Authority (NEMA) with administration and management of land use conflicts in the county. The 60 (15.5\%) of household respondents associated the National Land Commission with administration and management of land use conflicts in West Pokot County.

The Ministry was reformed by the devolved system of governance and institutions such as the Land Reform Technical Unit (LRTU), the Lands Information Management Systems Unit (NLIMS), and the National Titling Centre were established to enhance its effectiveness (Kameri-Mbote, 2016). The offices of the Ministry of Land and Physical Planning were also transferred from Trans-Nzoia County to West Pokot County. The Ministry of Land started to issue title deeds to residents from the headquarter of West Pokot County from 2015. In spite of all these efforts to reform and move the Ministry of Land closer to the residents, the household perception of it was low compared to the Ministry of Interior and Coordination of National Government. The Ministry of Interior and Coordination of the National Government which was a representative of the office of the

Table 2. Perceptions of household respondents on the efficacy of the institutions in the national government in managing land use conflicts in West Pokot County.

\begin{tabular}{ccc}
\hline & Frequency & Percent \\
\hline Min of Land & 93 & 24.2 \\
NLC & 60 & 15.6 \\
NEMA & 91 & 23.7 \\
Min of Interior & 126 & 32.8 \\
Others & 14 & 3.6 \\
Total & 384 & 100.0 \\
\hline
\end{tabular}

Source: Field data (2018). 
president wielded a lot of power from independence and is entrenched in the minds and hearts of residents of West Pokot County. Most household heads associated it with the administration and management of land use conflict compared to the Ministry of Land.

One of the most important achievements of the devolved system of governance in West Pokot County was to provide a framework that gives powers of self-governance to the people and enhances the participation of people in the exercise of the powers of the state and in making decisions affecting them. The Ministry of Land and Physical Planning and the County Government of West Pokot County facilitated the decentralization of the organs of Ministry of Land, Functions and Services from the region to the county. The county and national governments worked together to transfer the offices of the Ministry of Land and Physical Planning from Trans-Nzoia County to Kapenguria, the headquarter of West Pokot County.

The Ministry of Land and Physical Planning transferred the following functions to West Pokot County; the Department of Land Administration, Land Registration, Surveys and Settlement and Adjudication. The study found out that the Department of Land Registration had issued approximately 15,640 title deeds by March 2018 after it was transferred to West Pokot County. The Department was in the process of registering group ranches in Ortum West, Ortum East, Chepkobe, Kanyarkwat and Kongelai. It was also establishing Land Control Boards in West Pokot, Kipkomo and Pokot South. The land control boards will be tasked with the facilitation of subdivision of agricultural land, transfer of land, charge (loan financial or mortgages) and determination of the status of family selling land in order to protect family members from becoming landless, which was a cause of intracommunity conflicts in the county.

The Ministry of Land and Physical Planning also transferred the Department of survey to West Pokot County. The department was responsible for production, maintenance and distribution of accurate geographical data in form of various types of both analogue and digital maps in full range of scales. According to a respondent from the department

The work of the department was guided by Land Act 2012, Land Registration Act 2012, National Land Commission Act 2012, Surveyor Act CAP 299 and Land Adjudication Act. The department was expected to provide technical support to the county government, facilitate surveying and beaconing of group ranches in the county (Respondent, 2018a).

The other important department was Settlement and Adjudication. The department was responsible for demarcation of land and production of the title deeds. However, it was experiencing some challenges which were affecting their service delivery. One of the officers from the depart said that

There was a lot of work for the department yet it was encountering challenges which were affecting its performance. It had inadequate resources, 
few staff and it was not fully supported to perform its functions in the rugged and expansive county. For instance, similar departments in other counties have vehicles to facilitate officers' movement in the county but their office in West Pokot County did not have a vehicle. They were relaying on other departments to traverse the expansive county. However, they had managed to demarcate group ranches such as Kapsongaria, Tapach, Chobon and Cheparia but others were pending due to land cases in court. They were also waiting for the council of elders to settle boundary disputes in some group ranches before they could move in to demarcate and registration land (Respondent, 2018b).

The Ministry of Land was improving service delivery to the residents of West Pokot County. The transformed Ministry of Land and Physical Planning was addressing administration and management of land use which had contributed to escalation to land use conflicts in the county. Indeed, one of the respondents said that,

For the first time in more than fifty years after independence, West Pokot County residence was able to access services such as adjudication and registration of land from their own county. These were basic and accessible services to residents in other counties but the residents of West Pokot County were forced to incur extra cost to travel to Kitale town in Trans-Nzoia County to access services related to land administration and management. The absence of the Ministry of Land and Physical Planning in the county had led to discrimination and marginalization of the residents of West Pokot County from registering their land and they suffered many land use conflicts (Respondent, 2018c).

One of the officers in the Ministry of Land at the county government said that many families were experiencing land use conflicts because their land was never demarcated and not registered by their grandparents because the government did not provide the service to them. Their land was regarded as low potential area and the Ministry of Land did not establish its offices in the county. Now families are facing challenges on agreeing on land boundaries because if only two families settled on land in 1960s and it was not registered, those families have now grown into villages and it is difficult to ascertain land boundaries established by their grandparents.

The transfer of the Ministry of Land and Physical Planning from Trans-Nzoia County to West Pokot County actualized some key tenets of devolved system of governance. The national government institutions were moved closer to the people, improved service delivery, increased participation of the residents in decision making and prioritization of their development agenda and implementation using their elected leaders. The residents in the county were witnessing shared resources which were transferred from central government to West Pokot County Government compared to when appointed officers from the national 
government were tasked with such responsibilities at county level. The residents never participated in the planning and decision making about development initiatives in the county.

However, further decentralization of services delivery from the county headquarter to subcounties in West Pokot County will enable the residents to understand and appreciate the presence of the Ministry of Land and Physical Planning in the county. This was rightly observed by one of the respondents who said that,

it may appear as a very small issue or even irrelevant to some people from other counties that some residents of West Pokot County were celebrating the acquisition of the title deeds for their land yet the devolved system of governance ought to provide framework which can help residents to achieve a lot based on its objectives (Art. 174). But the acquisition of a title deed for their land was a remarkable achievement, since it had taken them over fifty years after independence to acquire it and it was becoming difficult to manage intracommunity and intercommunity land use conflicts since there were no officially demarcated land boundaries in most parts of the county. With the title deeds, some residents were sure that their land boundaries were clearly marked, it confirmed their security of right to land and that their land was protected from land grabbers. Land adjudication and registration had prevented many intracommunity conflicts in those areas where residents were issued with title deeds (Respondent, 2018d).

Thus, the Ministry of Land and Physical Planning was doing a lot to ensure effective administration and management land use in the county to prevent conflicts. However, there was need for the Ministry to transfer its services to subcounties in the county. This will ensure residents who are from farthest places will receive or access services.

The National Land Commission is a key independent institution which was established in the devolved system of governance to perform clear functions in administration and management of land use conflicts. The functions of the commission include to manage public land on behalf of the national and county governments; to advise the national government on a comprehensive programme for the registration of title in land throughout Kenya; to encourage the application of traditional dispute resolution mechanisms in land conflicts; to monitor and have oversight responsibilities over land use planning throughout the country among other functions yet only 60 (17\%) of household heads associated it with the administration and management of land use conflicts in the county (Art. 67(2) of the Constitution of Kenya, 2010).

However, the National Land Commission has encountered challenges from within and from other stakeholders. One of the respondents said that the commission has 47 county offices. The allocation of resources should be guided by the functions transferred to county offices. But the management of the commission had transferred many functions to the county offices without resources to 
implement them. The management had retained most of the resources at the national office in Nairobi. The commission office at the county was unable to deliver on its functions to the four subcounties in West Pokot County.

The National Land Commission has also experienced resistance from the Ministry of Land and Planning on its constitutional functions. The commission and the Ministry of Land have never amicable working relationship. The respondent said that the National Land Commission Act was amended in 2016. The amendment radically affected the mandate and functions of the commission. Some of the constitutional functions of the commission were returned to the Ministry of Lands yet it was the intension of the drafters of the constitution to transfer the functions to the commission. The original National Land Commission Act gave the commission jurisdiction over management of registry, planning and monitoring. The Supreme Court Advisory in 2016 about the functions of the commission and the Ministry of Land was very clear. However, the National Land Commission Act was amended to give the functions of the commission to the Ministry of Land. The commission was given advisory functions to the ministry.

In spite of all major achievements in administration and management of land use in West Pokot County, the Ministry of Land and Physical Planning and National Land Commission have a long way to ensure that land is used and managed in an equitable, efficient, productive and sustainable manner. The Ministry of Lands and NLC as institutions of national government must solve their difference and focus on administration and management of land use in order to prevent structural causes from breaking into violent land use conflicts.

\subsection{Efficacy of Institutions in the National Government Engaged in Administration}

The county governments established under Article 176 of the Constitution of Kenya 2010, consists of a county executive and a county assembly. The executive authority of the county is vested in, and exercised by the county executive committee which consists of the county governor and the deputy county governor; and members appointed by the county governor, with the approval of the assembly, from among persons who are not members of the assembly (Odote, 2013).

This section sought to examine the efficacy of institutions in the county government engaged in the administration and management of land use conflicts in West Pokot County. The result of the findings is illustrated in Table 3.

The results in Table 3 show that there are several institutions in the county government engaged in administration and management of land use. The result shows the perception of household head for all the institutions. The 218 (57\%) of household respondents linked the Ministry of Lands, Housing, Physical Planning and Urban Development to the administration and management of land use conflicts in West Pokot County. The 60 (16\%) of the household respondents associated Members of County Assembly with administration and management 
Table 3. Perception of household heads on the efficacy of the institutions in the county government engaged in administration and management of land use in West Pokot County.

\begin{tabular}{ccc}
\hline & Frequency & Percent \\
\hline MCA & 60 & 15.6 \\
County Governor & 20 & 5.2 \\
MLHPPUD & 218 & 56.8 \\
SC Administrators & 11 & 2.9 \\
Ward Administrator & 12 & 3.1 \\
Village Administrator & 4 & 1.0 \\
Village Council & 56 & 14.6 \\
Others & 3 & .8 \\
Total & 384 & 100.0 \\
\hline
\end{tabular}

Source: Field data (2018).

of land use conflicts, 56 (15\%) respondents associated council of elders, 20 (5\%) respondents associated the county governor and only $12(3.2 \%)$ of household respondents associated the ward administrators with administration and management of land use conflicts in West Pokot County. The results show that the household heads understand the role of the Ministry of Lands, Housing, Physical Planning and Urban Development in administration and management of land use in the county. The results also indicate that the household heads also recognized the role of the MCA (16\%) and council of elders (15\%) in administration and management of land use in the county. It means that the household heads were appreciating the council of elders whose role was recognized and integrated by the devolved system of governance in the administration and management of land use, unlike the centralized system of governance which marginalized and ignored their role and the community.

The devolved system of government puts the county government at the centre of administration and management of land use. The county government is assigned exclusive and concurrent authority and functions to engage in administration and management of land use in West Pokot County. The county government implements county legislation, national legislation, managing and coordinating the functions of the county administration and preparing proposed legislation. The County Governments Acts, read together with Article 186 and the Fourth Schedule of the Constitution also assigns the county executive committees some roles that relate directly or indirectly to land use in the county. Agriculture is one function assigned to county government and which deals with land use. The county government is also assigned the function of county planning and development. Under this role, the county government performs land survey and mapping, boundaries and fencing and housing (Odote, 2013). 
The fourth schedule tasks the county governments to implement specific national government policies on natural resources and environmental conservation, including soil and water conservation; and forestry. The county governments are mandated to ensure, coordinate and assist communities in developing administrative capacity for participation in governance at the local level. The County Government Act empowers the county governments to acquire, purchase or lease any land which may include community land, and to implement integrated development planning within the counties as well as within the cities and municipalities (Odote, 2013).

The Ministry of Lands, Housing, Physical Planning and Urban Development at the county level was implementing its functions which included county planning and development, that is, statistics, land survey and mapping, boundaries and fencing, housing, implementation of specific national government policies on land use in West Pokot County. It emerged from interviews and focused group discussions that the county government was positively implementing its mandate in land administration and management in the county. The county government was in the process of rolling out its services closer to the people in spite of the challenges such as inadequate resources and lack of capacity to deliver services to the lowest level of government." One of the officers in the Ministry of Land, Housing, Physical Planning and Urban Development said that devolution had helped the county to start addressing historical problems concerning land use based on their terms. Although the process was slow, the county government was taking one step at a time depending on availability of resources and personnel to implement its projects and it will ensure its services move from the county headquarter to the village level.

One of the successes that have been achieved under the county government and national government is the registration of land at the headquarter of West Pokot County. The process of registration of land is preventing and mitigating intractable and protracted land use conflicts in the county. For instance, a respondent from the Ministry of Land, Housing, Physical Planning and Urban Development said that

Lack of clear land boundaries and registration has affected some families who started living and sharing land as few members. The families have grown and expanded into villages on the same land. The sharing of unadjudicated and unregistered land is so complicated and surveyors are unable to demarcate the land. The conflicts have delayed registration of land (Respondent, 2018e).

The county government was working closely with the Ministry of Land and Physical Planning to fast-track registration of land. One of the respondents said that

It was the objective of the national and county governments to offer quality services to residents without indicating whether it was being offered by the 
national or county government. Second, officers in both governments were under the same roof to enhance service delivery in concurrent functions and therefore it was difficult for the residents to make a distinction between the function of national and county governments. Third, both national and county governments did not have adequate staff to deliver services demanded by all residents of West Pokot County. The governments had consolidated the available human resources to deliver very important services as it mobilized for more resources in order to reach many residents in need of services (Respondent, 2018f).

According to Odote (2013), the county assembly is very important players in the management of land use in the county. Article 185 of the Constitution and the County Government Act gives the county assembly powers to perform their functions which include making necessary laws, exercise oversight over the county executive committee and any other county executive organs and approve plans and policies for the management and exploitation of the county's resources, infrastructure and institutions. The role of the county assembly approving the budget and expenditure of the county government and approving county development planning contributed to management of land use by the county government.

The county assembly was playing its constitutional roles administration and management of land use in West Pokot County. The assembly passed laws such as West Pokot County Urban Planning Act, 2016 whose objective was classification of areas as urban, governance and management of urban areas and participation by the residents in the governance of urban areas. The laws are necessary for the county government to effectively perform its functions and exercise its powers. The assembly exercises oversight over the county executive committee and any other county executive organs, receive and approve plans and policies for the management and exploitation of the county's resources and the development and management of its infrastructure and institutions (Art. 185). It was also tasked to perform any other role as may be set out under the Constitution or legislation (County Government Act No. 17 of 2012).

It emerged from interviews with an officer from West Pokot County Assembly who observed thatassembly was performing its functions of law making, oversight, validation, representation, allocation of resources and the MCAs were also engaged in development activities in their wards. The facilitative role of the county assembly enabled the residents to get title deeds, build offices and transfer offices of the Ministry of Land and Physical Planning to county headquarter, allow the county government to employ officers to support the Ministry of Land and Physical Planning officers, allocated funds to facilitate registration of public, community and private lands, fight corruption related to survey fees and cartels in the ministry. The assembly assisted in increasing acreage of land under irrigation in Lodikiri, open more areas for irrigation in Pokot Central, tubing water in Sebit area to increase food production and use of technology to improve animal 
rearing and pastoralism.

The members of the committee on land in county assembly of West Pokot County said that

The county assembly shares information with the public on land laws discussed in the chamber. The county assembly was discussing land valuation laws to enable the county government achieves its objective of developing at least two urban centre in each ward in the county. One of the issues that were being discussed by the assembly was how to establish a law which could allow the county government to hire its own land valuer. The valuer provided by the national government was serving the entire region, which includes Uasin Gishu, Trans-Nzoia, West Pokot and Turkana County. Lack of the services of the valuer was delaying the county to achieve its development plan in towns, municipality and urban centres. The investors were unable to invest in the county because the value of land was not determined in some areas.

The assembly was also performing its role of receiving and approving plan and policies for the management and exploitation of the county's resources. The chair and deputy chair of the committee said that

The Assembly was also discussing policy on physical planning of towns, urban centres and municipality in West Pokot County. The policy will provide direction on development of urban centres. This is because development was a head of planning in West Pokot County. The assembly was hastening town planning to ensure investors do not lose their property when the county government develops the plan which may cause demotion and court cases for compensation due to roads passing through investors' building.

The member of Committee on Land in the county assembly said that the assembly was addressing marginalization caused by the 1965 Sessional Paper No. 10 which excluded West Pokot County from high potential areas. It was also combating corruption by giving leaders amnesty of returning grabbed land from county. Some leaders had voluntarily returned land to county government.

The office of the governor established a department of disaster and conflict management. The office was tasked with management of conflicts in the county and it was working with neighboring counties such as Turkana and Elgeyo/Marakwet to put in place measures for managing land use conflicts on the borders. During data collection for this study, the West Pokot and Turkana Counties organized consultative meeting on the border of the two counties to discuss the causes and measures for preventing such conflicts. On the other hand, the West Pokot Governor in consultation with his colleague in Elgeyo/Marakwet were working together to stop land use conflicts in Chesegon/Kerio Valley. The conflict was 
displacing many households, destroying property and some people lost lives in February 2018 before the conflict was stopped and peace agreement signed in 2019 (Wu, 2019).

\section{Conclusion}

The national government, county government and National Land Commission have influenced administration and management of land use which has prevented intractable and protracted conflicts in the county. The transfer of the Ministry of Land and Physical Planning to West Pokot County was a major achievement courtesy of devolution. From the time it was moved to the county headquarter, the registration, survey and adjudication and settlement departments had improved land use administration and management in some subcounties. The adjudication office had demarcated several blocks of land in the county. The national and county governments were partnering together to fast-track access, ownership and effective use of land to achieve its sustainable and productive management of land use. The transparent, accountable and cost-effective administration of land was a good mechanism preventing intracommunity and intercommunity conflicts in the county. The partnership was evident by the meetings and joint activities organized by the Ministry of Land and Physical Planning and the Department of Lands, Housing and Urban Planning to develop the best and cost-effective ways to enhance land administration and management in West Pokot County. The forums brought together various stakeholders in the county, enhanced mobilization of scare resources, participation of the public in decision making and ownership of the process by the residence which was aimed at improving administration and management of land use in the county.

\section{Recommendation}

The study recommends that full implementation of the devolved system of governance will go a long way in managing land use conflicts in West Pokot County. The institutions at national and county governments have immense responsibility in improving administration and management of land use conflicts from national to county level. Adequate financial, human capacity and technology support and further decentralization of the institutions in the devolved system of governance closer to the grassroot will go a long way in the management of land use conflicts in West Pokot County.

\section{Acknowledgements}

The researchers are grateful for the support from the Department of Peace and Conflicts (PCS) during the research period. Appreciation to the West Pokot County and all respondents who shared their time and information with the authors. We also thank everyone who directly or directly contributed to the success of this study. 


\section{Conflicts of Interest}

The authors declare no conflicts of interest regarding the publication of this paper.

\section{References}

(2018) Interview with County Commissioner, West Pokot County.

Agrawal, A. et al. (2006). Decentralization and Environmental Conservation: Gender Effects from Participation in Joint Forest Management. International Research Workshop on Gender and Collective Action, Chiang Mai, Thailand

Babbie, E. (2007). The Practice of Social Research (11th ed.). Belmont, MA: Thomson Higher Education.

Bogaards, M. (2002). Consociational Parties and Political Accommodation in Ethnoplural Societies. ECPR Joint Sessions, Turin Workshop 5. Department of Politics, University of Southampton.

Boone, C. (2012). Land Conflict and Distributive Politics in Kenya. African Studies Review, 55, 75-103. https://doi.org/10.1353/arw.2012.0010

Bosire, C. M. (2013). Devolution for Development, Conflict Resolution, and Limiting Central Power: An Analysis of the Constitution of Kenya 2010. PhD Thesis, Cape Town: University of Western Cape.

Bryman, A., \& Teevan, J. J. (2005). Social Research Methods. Oxford: Oxford University Press.

County Government of West Pokot (2014). West Pokot County Annual Development Plan 2015/2016.

http://www.westpokot.go.ke/images/downloads/generaldownloads/ADP/WESTPOKO T-County-Annual-Development-Plan-2015-2016.pdf

Dulock, L. H. (1993). Research Design: Descriptive Research. Journal of Pediatric Oncology Nursing, 10, 154-157. https://doi.org/10.1177/104345429301000406

Government of Kenya (2010). The Constitution of Kenya. Nairobi: Government Printer.

Government of Kenya (2012). County Government Act No. 17 of 2012. Nairobi: Government Printer.

Hornsby, C. (2012). Kenya: A History since Independence. London: I.B. Taurus. https://doi.org/10.5040/9780755619023

Huho, J. M. (2012). Conflict Resolution among Pastoral Communities in West Pokot County, Kenya: A Missing Link. Academic Research International, 3, 458-468.

Kameri-Mbote, P. (2016). Kenya-Land Governance Assessment Report (English). Washington DC: World Bank Group. https://doi.org/10.1596/28502

http://documents.worldbank.org/curated/en/829991504864783043/Kenya-Land-govern ance-assessment-report

Kanyinga, K., Lumumba, O., \& Amanor, S. (2008). The Struggle for Sustainable Land Management and Democratic Development in Kenya: A History of Greed and Grievances. In S. K. Amanor, \& S. Moyo (Eds.), Land and Sustainable Development in Africa (pp. 100-126). London: Zed Books. https://doi.org/10.5040/9781350220997.ch-004

Lijphart, A. (1999). Patterns of Democracy: Government Forms and Performance in Third-Six Countries. London: Yale University Press.

Manji, A. (2014). The Politics of Land Reform in Kenya 2012. African Studies Review, 57, 115-130. 
Masinde, I., Adan, M., \& Pkalya, R. (2004). Indigenous Democracy: Traditional Conflict Resolution Mechanisms, Pokot, Turkana, Samburu and Marakwet (p. 17).

Mwenda, A. (2010). Devolution in Kenya: Prospects, Challenges and the Future. London: Institute of Economic Affairs. http://www.ieakenya.or.ke

Nangulu, A. K. (2009). Food Security and Coping Mechanisms in Kenya's Marginal Areas: The Case of West Pokot. Dissertation, Morgantown, WV: The Eberly College of Arts and Sciences, West Virginia University.

Nyberg, G., Knutsson, P. et al. (2015). Enclosures in West Pokot, Kenya: Transforming Land, Livestock and Livelihoods in Drylands. Pastoralism: Research, Policy and Practice, 5, 25. https://doi.org/10.1186/s13570-015-0044-7

https://pastoralismjournal.springeropen.com/track/pdf/10.1186/s13570-015-0044-7

Nyukuri, B. K. (1997). The Impact of Past and Potential Ethnic Conflicts on Kenyan's Stability and Development. The USAiD Conference on Conflict Resolution in the Greater Horn of Africa, Nairobi, 8, 12.

Odote, C. (2013). The Legal and Policy Framework Regulating Community Land in Kenya An Appraisal. Nairobi: Friedrich Ebert Stiftung.

Ogecha, A. P. (2016). Water Conservation Projects and Household Food Security in Kitui County, Kenya. PhD Thesis, Kakamega: Masinde Muliro University of Science and Technology.

Ouma, O. S. (2011). Constitutional Mechanisms for the Management and Settlement of Identity Conflicts: The Cases of Sudan, Kenya and Somalia. PhD Thesis, Rome: Luiss University of Rome.

Oyugi, W. O. (2000). Conflict in Kenya: A Periodic Phenomenon. The International Conference on African Conflicts: Their Management, Resolution, and Post-Conflict Reconstruction, Addis Ababa, 13-15 December 2000.

https://citeseerx.ist.psu.edu/viewdoc/download?doi=10.1.1.550.1709\&rep=rep1\&type= pdf

Pkalya, R., Adan, M., \& Masinde, I. (2004). Indigenous Democracy: Traditional Conflict Resolution Mechanisms, Pokot, Turkana, Samburu and Marakwet (pp. 1-105). In R. Betty, \& K. Martin (Eds.), A Publication of ITDG-EA.

Pragya (2013). Conflict Assessment, Northern Kenya: Development without Destruction. Empowerment for Enabling Choice. Nairobi. http://www.pragya.org

Respondent (2018a). Interview. West Pokot County, Kenya: The Ministry of Land and Housing, Physical Planning and Urban Development.

Respondent (2018b). Interview. West Pokot County, Kenya: The Ministry of Land and Housing, Physical Planning and Urban Development.

Respondent (2018c). Interview. West Pokot County, Kenya: The Ministry of Land, Housing, Physical Planning and Urban Development.

Respondent (2018d). Interview. West Pokot County, Kenya: The Department of Survey, Ministry of Land and Physical Planning

Respondent (2018e). Interview. The Lands and House Committee, the County Assembly of West Pokot County Government, Kenya.

Respondent (2018f). Interview. The Lands and House Committee, the County Assembly of West Pokot County Government, Kenya.

Roberts, J. M. (2009). Conflict Analysis of the 2007 Post-Election Violence in Kenya. Director of Conflict Recovery, New Dominion Philanthropy Metrics.

http://ndpmetrics.com/papers/Kenya_Conflict 2007.pdf 
Wolff, S. (2012). Consociationalism: Power Sharing and Self-Governance. In S. Wolff, \& C. Yakinthou (Eds.), Conflict Management in Divided Societies: Theories and Practice (pp. 1-34). London: Routledge. https://doi.org/10.4324/9780203803004

Wu, Q. (2019). Calm Returns to Kenya's Troubled Region after Leaders Ink Peace Pact. Xinhua. http://www.xinhuanet.com/english/2019-08/01/c 138276060.htm

Zar, J. H. (1984). Statistical Analysis (2nd ed.). Englewood Cliffs, NJ: Prentice-Hall, Inc. 